\title{
Community Involvement Towards a Circular Economy: a Sociocultural Assessment of Projects and Interventions to Reduce Undifferentiated Waste
}

\author{
Beatriz Michelle Bringsken ${ }^{1}$, Isabel Loureiro ${ }^{2}$, Carlos Ribeiro ${ }^{3}$, Cândida Vilarinho ${ }^{4}$ and \\ Joana Carvalho 4,5
}

\begin{abstract}
.
In a Circular Economy, waste is a resource with potential to be valued. This concept idealized almost 30 years ago is still vague in its practical implementation process. This study evaluates from a social perspective the tendency to integrate resources into the waste management to answer the question: "How sociocultural perspectives on waste within a community could influence interventions and projects towards a circular economy?". Therefore, organized communities in the municipality of Guimarães and the University of Minho (UMinho), in the north of Portugal, were chosen as case study and strategies were analysed. The first part of this study focuses on evaluating the impact of a community project known as 'Brigada Verde' implemented in about 20 parishes in Guimarães. The second part relates to assisting in the policymaking process of a Sustainability Plan at UMinho; and the final section assesses best-practices for waste created by agents who took initiative towards a Circular Economy. The research objective is to evaluate how community strategies effectively achieve results according to several indicators as values, changing behaviours and creating solutions to waste.
\end{abstract}

Keywords: Sociology of Waste, Policymaking, Circular Economy, Best-practices benchmarking.

\section{Introduction}

In Portugal, the responsibility to manage the undifferentiated waste from domestic and non-domestic users (for less than 1100 litters) is on the municipal government (Borges, 2017). The city of Guimarães has already filled up one of its landfills, so waste is a concern. A circular economy is a tool to avoid overloading landfills, so it is crucial for society to incorporate source separation practices reducing the undifferentiated waste. The local government in Guimarães has developed several projects to bring awareness about sustainability to its inhabitants. The University of Minho shares the same concern related to sustainability and released a new Sustainability Plan that pretends to reduce the use of plastic in the bars and canteens. Therefore, the aim of this study is threefold focused on identifying changes out of a social process by: monitoring the action plans and interventions of a community project known as Brigada Verde (Green Brigades); by evaluating the implementation of a Sustainability Plan at the 
University of Minho and lastly by categorizing best-practices in a transitional process towards a Circular Economy.

Initially it is important to understand the historical drivers that influenced the sociocultural context of Guimarães, a city which has a concentrated industrial sector, attracts tourists because of the UNESCO World Heritage and receives thousands of students at the University of Minho. Guimarães is known for its industrious area for leather and textile, but those industrial activities damaged the environment, mainly the water resources (Alves, 2002). According to the researcher Elizabeth Pinto (2012), there has been a long history of spreading unhealthiness in Guimarães and what used to be a social and financial concern, became today an environmental problem (p. 13). Regarding the municipal waste, until 2004 the source separation of residues from the local industry was almost nonexistent, there was little environmental concern. In 2012, Guimarães was recognized as European Capital of Culture. Urban renewal and new cultural spaces were the goals of this event that crucially changed the image of the city. To measure the impact of that project, several citizens were informally interviewed, and the impressions were published in June 2013 on the report "Guimarães 2012 Capital Europeia da Cultura Impactos Económicos e Sociais". Most respondents were satisfied with the changes: "Our city is a bit cleaner after becoming the Capital of Culture, also because of the tourists that come, we have to keep it beautiful', said one mid-age lady who lives in Guimarães.

Therefore, the current political drivers have brought an environmental concern and gave space to sustainable projects to improve the waste management in the city. Several local communities - politically known as parishes - got organized as Green Brigades to establish voluntary agreements and to care about their community. In 2017, Guimarães was recognized as one of the three most sustainable cities in Portugal; Five parishes joined the first edition of the Portuguese National Contest Eco-Freguesias XXI 2017 and Guimarães was the municipality with the highest number of parishes awarded. The city joined the contest to become the European Green Capital 2020 and ended up ranked with the $5^{\text {th }}$ position being Governance Indicator ranked with the $2^{\text {nd }}$ position The activities implemented for this contest were documented in several editions of the magazine 'Guimarães Mais Verde' and used as data to select the interventions related with the Green Brigades.

The University of Minho established a good relationship with the local government in Guimarães, collaborating through a research center known as Laboratorio da Paisagem (LdP). UMinho was considered the first most sustainable Portuguese university for it was ranked as $48^{\circ}$ in the UI Green Metric World University Rankings 2017. The second part of the research, focused on UMinho, because the university has a social responsibility to teach its students, the educated ones have a higher probability of becoming change makers and role models for applying the knowledge acquired. The literature review concerned the cultural context of UMinho indicated that the community is proud to be the first Portuguese university to develop a Sustainability Report Plan. When these local communities get organized to establish their shared social motivations, there is huge potential and effectiveness for achieving the goals towards a better future.

A recent study indicated that source separation of undifferentiated waste in Guimarães still needs to be improved, mainly organic residues and textile (Sepúlveda, 2017). These two materials - organic and textile - were identified as barriers and 
opportunities for the local community to experience a Circular Economy. In the third part of this study, the impacts of good practices from individuals that inspire others to change behavior towards waste will be described. All those three cases will be studied under an integrated approach to understand how involved local communities experience the Circular Economy's concept. This study aims to evaluate sociocultural processes in three different levels of communities by performing interviews, questionnaires, focus groups, experiments and observing the implementations of action plans.

\section{Literature Review}

There is a vast literature on the Sociology of Waste as well as on Circular Economy, but few of those papers reviewed have those two concepts intertwined. The common topic concerns were on environmental aspects such as water and pollution, or also on the Environmental Psychology area. Following those two keywords, the gap found among the analyzed academic papers concerned undifferentiated waste and its relation to the sociocultural process within a community. The research found on Circular Economy pointed out that there is still confusion whether it is a new concept or a revitalization of pre-existing ideas.

Table 1. Summary of literature review

\begin{tabular}{|l|l|l|l|}
\hline & Main contribution & Diverging point & References \\
\hline 1 & $\begin{array}{l}\text { Sociological Reflections on Governing } \\
\text { Waste. }\end{array}$ & $\begin{array}{l}\text { Only focused in } \\
\text { Ireland. }\end{array}$ & Honor Fagan (2003) \\
\hline 2 & $\begin{array}{l}\text { Sociological Approaches to Waste as a } \\
\text { Social Problem: Environmental } \\
\text { Burden, Race, Class, and Place. }\end{array}$ & $\begin{array}{l}\text { Social impact from } \\
\text { waste facilities. }\end{array}$ & Elizabeth Roby (2014) \\
\hline 3 & $\begin{array}{l}\text { Theoretical Approach to the } \\
\text { Collaborative Environmental } \\
\text { Activities: Household Waste Disposal } \\
\text { towards Environmentally Friendly } \\
\text { Daily Life. }\end{array}$ & $\begin{array}{l}\text { Only focused in } \\
\text { Finland. }\end{array}$ & Shino Koda (2012) \\
\hline 4 & $\begin{array}{l}\text { Pro-environmental behavior from a } \\
\text { Social Cognitive Theory Perspective. }\end{array}$ & $\begin{array}{l}\text { Focused on the } \\
\text { individual } \\
\text { agent/actor. }\end{array}$ & Dian R. Sawitri (2015) \\
\hline 5 & $\begin{array}{l}\text { Conceptualizing the circular economy: } \\
\text { An analysis of 114 definitions. }\end{array}$ & $\begin{array}{l}\text { Theoretical } \\
\text { approach of CE. }\end{array}$ & Julian Kirchherr (2017) \\
\hline 6 & $\begin{array}{l}\text { Improving regional waste management } \\
\text { epistemic object. }\end{array}$ & $\begin{array}{l}\text { Only focused on } \\
\text { perspectives of CE. }\end{array}$ & $\begin{array}{l}\text { Joacim } \\
\text { (2017) }\end{array}$ \\
\hline
\end{tabular}

One of the reasons why the concepts related to Sociology of Waste and its sociocultural impact are not intertwined with the Circular Economy might be because the focus on the $\mathrm{CE}$ has been more on the economic and environmental concerns. Behaviours towards waste or sustainability have been studied regarding the individual level or related to a specific country, but there are many levels as family and community that were not found 
in the literature reviewed. Therefore, the classical Social Theories that were selected to support this research on Circular Economy were incorporated on this review.

Table 2. Social Theories related to Circular Economy

\begin{tabular}{|c|c|c|c|}
\hline Theory & Definition & $\begin{array}{l}\text { Scope } \\
\text { Application }\end{array}$ & Usages of the model \\
\hline $\begin{array}{l}\text { Theory of } \\
\text { Planned } \\
\text { Behaviour } \\
\text { (Ajzen, 1985). }\end{array}$ & $\begin{array}{l}\text { Theory of planned } \\
\text { behavior is determined } \\
\text { by intention to } \\
\text { perform / attitude or } \\
\text { perceived behavioral } \\
\text { control / subjective } \\
\text { norm. }\end{array}$ & $\begin{array}{l}\text { Disease prevention } \\
\text { behavior, birth } \\
\text { control behavior, } \\
\text { consumption } \\
\text { prediction, whether } \\
\text { to wear a seat belt or } \\
\text { not. }\end{array}$ & $\begin{array}{l}\text { Provides instructions for } \\
\text { designing questionnaires } \\
\text { (attitude/value rating } \\
\text { scales). } \\
\text { Provides information on } \\
\text { development of } \\
\text { communication strategies/ } \\
\text { evaluation studies. }\end{array}$ \\
\hline $\begin{array}{l}\text { Social } \\
\text { cognitive } \\
\text { theory } \\
\text { (Bandura, 2001). }\end{array}$ & $\begin{array}{l}\text { Explains how people } \\
\text { acquire } / \text { maintain } \\
\text { certain behavioural } \\
\text { patterns, with factors } \\
\text { as environment and } \\
\text { people. }\end{array}$ & $\begin{array}{l}\text { Relevant for } \\
\text { designing health } \\
\text { education and health } \\
\text { behavior programs. }\end{array}$ & $\begin{array}{l}\text { SCT provides a framework } \\
\text { for designing, implementing } \\
\text { and evaluating programs; } \\
\text { Provides the basis for } \\
\text { intervention strategies. }\end{array}$ \\
\hline $\begin{array}{l}\text { Observational } \\
\text { learning } \\
\text { (Bandura, 2001). }\end{array}$ & $\begin{array}{l}\text { Occurs when a person } \\
\text { watches the actions } \\
\text { and outcomes of } \\
\text { another one; and } \\
\text { receives } \\
\text { reinforcement } \\
\text { /capability to perform } \\
\text { a behavior. }\end{array}$ & $\begin{array}{ll}\text { Relevant } & \text { for } \\
\text { ethnocultural } & \\
\text { studies. } & \end{array}$ & $\begin{array}{l}\text { Provides credible role } \\
\text { models of the targeted } \\
\text { behaviour and the skills to } \\
\text { perform it. } \\
\text { Basis for Focus Group and } \\
\text { anthropological studies. }\end{array}$ \\
\hline $\begin{array}{l}\text { Groupthink } \\
\text { (Irving, 1982) }\end{array}$ & $\begin{array}{l}\text { A highly cohesive } \\
\text { group, isolated from } \\
\text { contrary opinions, and } \\
\text { ruled by a leader who } \\
\text { is too confident and } \\
\text { ignores contingency } \\
\text { plans. }\end{array}$ & $\begin{array}{lr}\text { Interesting } & \text { for } \\
\text { decision } & \text { making } \\
\text { processes } & \text { and } \\
\text { governance. } & \end{array}$ & $\begin{array}{l}\text { Provides tools to recognize } \\
\text { the dangers of groupthink: } \\
\text { limits discussion; initial } \\
\text { solution is never restudied; } \\
\text { any experts opinion; highly } \\
\text { selective in gathering } \\
\text { information. }\end{array}$ \\
\hline $\begin{array}{l}\text { Network } \\
\text { theory (Mouge, } \\
\text { 2003). }\end{array}$ & $\begin{array}{l}\text { Focuses on: } \\
\text { relationships between } \\
\text { people, feelings and } \\
\text { the exchange of } \\
\text { information, goods } \\
\text { and money. }\end{array}$ & $\begin{array}{l}\text { Used to study } \\
\text { organizational } \\
\text { phenomena, control } \\
\text { over information, } \\
\text { communication and } \\
\text { influences. }\end{array}$ & $\begin{array}{l}\text { By mapping relationships } \\
\text { and emergent patterns, } \\
\text { uncovers } \\
\text { communication patterns } \\
\text { and structures. Basis for } \\
\text { Interviews and surveys. }\end{array}$ \\
\hline
\end{tabular}

It is well known that education campaigns regarding environment are very effective at schools, the younger the child the better. However, there is another factor of influence that is not so obvious: a school is a community. It means that there are variables as role models and peer pressure, influencing or controlling behaviors, that are determining the 
social environment and triggering behavior change. A community is a dynamic involving organism influenced by a groupthink aspect given by the impression that a specific group is the dominant one because of power or number of members. Outside of a limited physical space like a school, university or neighborhood, it is the media who gives us the impression of what the dominant group must focus on.

A community is also a nurturing space to gather data from observational learning and its impact on source separation practices. Social cognitive theory and Theory of Planned Behaviour are necessary to develop a strategy aligned to the community targeted; The network theory facilitates the monitoring activities. Engaging, involving, exemplifying, leading by example, encouraging and enabling, all those actions are determined by sociocultural factors that influence interventions and projects.

\subsection{Research question and research objectives}

The main research question is: "How sociocultural perspectives on waste within a community could influence interventions and projects towards a circular economy?". This study has three folded specific objectives based on different cases: Green Brigade, University of Minho and the emerging strategies out of those two mentioned communities towards Circular Economy.

1) "What triggers a community to mobilize themselves as Green Brigade acting towards a shared common goal?". This first research objective is focused on the mobilization of community-based organizations (CBOs) as the Green Brigades, which is an eco-activism involving 20 out of the 48 parishes in Guimarães. Monitoring the impact of activities and mobilization campaigns requires indicators to measure the objectives planned and achieved on waste separation. To define indicators is necessary to know better the characteristics of the communities, they could be driven by different motivations, such as cleaning up their neighborhood or earning an income from solid waste. A strong sense of community often helps to stimulate participation, but community members play different roles and present different levels of involvement. Some communities are also documenting their actions on websites, as for instance the Lapinha-Vizela (lapinhavizela.wordpress.com/).

The data presented about Green Brigades in Guimarães was collected on March 24, 2018, during a conference at the research center Laboratorio da Paisagem. The representative of the Brigada Verde (BV) from Caldelas parish, José Fonseca, believes that the best way to reach the adults is by teaching children at schools. He explained that the community holds a joint meeting to write the plan of action on how to involve associations of the parish. The main values that the $\mathrm{BV}$ in Caldelas wants to communicate are consistency, continuity of purpose and resilience. The main interest is to bring together people that care about the environment, independent if they want to join the organization or not.

In 2017, Guimarães was recognized as the municipality with the most awarded eco-parishes at national level, in the same contest, the parish of Fermentões was ranked as the 5th best one (Gomes, 2017). Another case is the Green Brigade from Creixomil parish, which has only one year of existence, but already receives support from the local government to enforce the rehabilitation of forests and accomplish other small actions. The support from the environmental research center Laboratorio da Paisagem, located in 
Creixomil, is an important part of the success of this recently organized group. Regarding selective waste collection, there is a lack of good practices and they are aware that it takes time to change, but they do not want to "give up the fight". One of the main activities is to challenge children to be environmental defenders.

There is a discussion among the brigades about the possibility of joining forces with other parishes since 100 people together would have greater impact than twice 50 divided into two parishes. A real concern is the new way of life in which people are more isolated and less involved with their surroundings. The non-members refuse to get involved believing that they act accordingly well by themselves. There are about 20 green brigades with more than 2000 agents, but this research will focus on monitoring 3 interventions and 3 projects related to the selective waste.

2) "What are the communication patterns or structures when shared responsibility on waste is perceived by different stakeholders and actors at the University of Minho?". The second research objective focuses on the perceived shared responsibilities while implementing actions. After analyzing communities in neighborhoods, it was interesting to search for another level of community involvement, it could have been industry, commerce or restaurants. The reason why UMinho's community was chosen is that academic knowledge plays a direct role in society and carries a social responsibility. It would be necessary to understand how the agents from this academic space perceive their responsibility on waste. The SASUM (Serviços Ação Social) and the Management Council are two committees sharing the responsibilities for sustainability plans inside UMinho, but this fact causes confusion to determine accountability. Institutional fragmentation in waste management makes it harder to move forward and leads to a different course from the Circular Economy concepts. However, this could be prevented by asking for authority and responsibility clarifications while designing a tool as the Responsibility Assignment Matrix (RAM).

Responsibility is a practical issue. For instance, there is a fine line distinguishing who is responsible to prevent that bars inside the campi offer or not plastic cups to their client. Should it be consumers, the Board of Managing Directors or each bar should be free to decide based on their infrastructure? For this research objective, the selected indicators will point towards accountability and alignment of values. In 2004, students of Communication Studies decided to launch a campaign to reduce organic waste from the restaurants and canteens at UMinho, known as the movement "Menos olhos do que barriga" (smaller eyes than stomach), it was a very successful intervention with posters and personal approach. This is an example that students can also take responsibility and be involved to develop actions regarding waste.

To collect data about the decision-making process and stakeholders for this second research objective, it would request a closer involvement with regulations and projects on sustainability at UMinho. Therefore, on the $15^{\text {th }}$ of March 2018, during a meeting at SASUM, it was established that the researcher of this paper would collaborate with UMinho regarding communication strategies for sustainability. After the second meeting at SASUM, on the 4th of April, it was suggested to collect data about food waste from the restaurant kitchen to develop a course material for capacity on reducing waste. It was a great opportunity to talk with the employees at the canteen and bars while putting in practice the observational learning process. Besides getting involved with 
policymaking and implementations on the Sustainability department, the researcher will also cooperate with the Communication department by suggesting articles to be published on the university's newspaper, as well as organizing clean-up interventions, pilot experiments with innovations and events focused on waste concerns.

3) "What are the best practices with social impact of grassroots movements that close loops on resources and lead to a Circular Economy?". Third specific objective is to analyse best practices with social impact on grassroots movement.

The European Union has been promoting waste valorisation and recycling of materials within its member-states. In this sense, Guimarães is making progress with the PAYT (pay as you throw) system, which is a social innovation focused on the four main recyclable materials- glass, paper, plastic and metal, but not on the organic and textile waste. Even materials as gums and cigarette butts received attention and two innovative projects known as Papa-chicletes (gums containers) and EcoPontas (cigarette butts containers) were implemented in the main areas of the city since 2016. So, that is why the two initiatives selected for this research objective involves textile and organic waste. In this preliminary study two grassroots movements were identified:

(1) Quinta Vedeiros is a small farm located about 300 meters away from the campus of UMinho in Guimarães. Nuno Oliveira is responsible for the organic farming, and for several months he has been collecting per week about 20 kilos of coffee grounds from the bars of the university for composting. The valorisation of what would be considered waste closes the loop for this resource. This is a very promising movement since composting in urban areas has a huge potential for promoting urban agriculture. Besides that, the local government grants small areas of community gardens to families with low income to practice urban agriculture. However, there is no organized selective collection of coffee grounds in the bars and restaurants of Guimarães, while it could close the loop for resources to composting. When the organic waste ends up in the landfill, it releases greenhouse gas emissions (methane), while if it was properly sorted out the organic material could increase the rates of composting material produced. In Guimarães, the organic material represents $36.42 \%$ of the undifferentiated waste collected by the municipality (Sepúlveda, 2017).

(2) Guimarães has a strong textile industry and a high number of tailoring shops. Due to the large textile industry, it reaches on average $5.32 \%$ of clothing material out of the total composition of undifferentiated waste collected by the municipal waste management (Sepúlveda, 2017). However, this number increases if considering specific collection areas (circuit 3B) near the textile industry, where this percentage reaches $27 \%$ of textile collected with the undifferentiated waste. However, a garment collecting campaign launched in 2013 by the international company H\&M has changed the waste destination of several tailoring shops in Guimarães. This top-down intervention is very successful in Guimarães where several clients drop off their old clothes at the tailoring shops, then the dressmakers donate it to H\&M stores.

\section{Methodology}

Monitoring indicators are used to evaluate the effectiveness of strategies, they need to be linked with results and actions under each strategy to be identified, as well as 
specific objectives and impacts of implemented activities. It helps to ensure integration or to test acceptance of policies and innovation. Indicators can only reduce uncertainty on the monitoring process when it is based on good data, achieved targets and when it takes sociocultural values into account. In this case, indicators will reflect social contexts and could turn information into knowledge. These are the 3 sets of indicators selected based on preliminary study for each research objective:

1. Indicators to be used to evaluate and monitor the Green Brigades: selection of actions, littering/cleaning the environment, citizen involvement or participation, influencing actors, level of public participation, community integration, barriers and attitudes, habits and motivations, key behaviours for great effects, civic pride of the city/parish, social pressure and interactions.

2. In the second objective, the indicators could assist in policymaking: proactive policy, strategic framework, role as stakeholders, governance, commitment to sustainability / waste as priority, undifferentiated waste intensity, resource management and recycling, distance of the deposit bin, pride of the image of the university, paying attention and listening to the ones affected by the policy.

3. The indicators to be used to develop a performance assessment of best practices on social business initiatives are the ones aligned with a circular economy: collaboration, innovation, social business, creativity, financial and human resources, life cycle thinking, consumption habits and effort time consumption of the new activity.

\section{Description of Tasks Timeline and Methods}

Table 3. Indicative timelines for expected results to be achieved.

\begin{tabular}{|l|l|l|l|}
\hline 2 years April 2018-2020 & $\begin{array}{l}\text { How } \\
\text { Long }\end{array}$ & Due date \\
\hline 1. & $\begin{array}{l}\text { Collect data! } \\
\text { - Identify main actors directly or indirectly related to the selected } \\
\text { activities; } \\
\text { Design focus groups, interviews and questionnaires; } \\
\text { - Use the SMART method to evaluate efficiency of initiatives; } \\
\text { - Analyze frameworks and policies, Communication plans and } \\
\text { Conducted status meeting. }\end{array}$ & $\begin{array}{l}\text { Content } 2018 \\
\text { Monitor systematic gathering and analyze information that will } \\
\text { help measure progress on an aspect of the project; } \\
\text { Gathering data through internal reporting, continuous check of } \\
\text { status quo, analysis of deviations; } \\
\text { - UMinho: Mapping and situation analysis of waste separation, } \\
\text { initiatives working on reducing waste flows; } \\
\text { Questionnaires approved and done; interviews and focus } \\
\text { groups prepared test and data collection. Quantify and qualify } \\
\text { impact. }\end{array}$ & Jan. 2019 \\
\hline
\end{tabular}




\begin{tabular}{|l|l|l|l|}
\hline 3. & $\begin{array}{l}\text { Assessing performance! } \\
\text { Create a Responsibility Assignment Matrix (RAM) } \\
\text { Pilot-tests for reception of policies. } \\
\text { Ensure integration of practices. }\end{array}$ & 4 months & May 2019 \\
\hline 4. & $\begin{array}{l}\text { Evaluate data! } \\
\text { Data analysis: determine the variables and their relationships, } \\
\text { calculate basic statistics, and present results clearly, including } \\
\text { how to deal with missing data, variable groups, and graphs. }\end{array}$ & 3 months & $\begin{array}{l}\text { August } \\
2019\end{array}$ \\
\hline 5. & $\begin{array}{l}\text { Interpret data! } \\
\text { Write a thesis that will assist in policymaking and will evaluate } \\
\text { actions and practices. }\end{array}$ & $\begin{array}{l}\text { The final scope of these tasks is to write a scientific article for } \\
\text { publication in journals (at least } 4 \text { articles will be published } \\
\text { throughout the project) to have participation in Scientific } \\
\text { Conferences for and consequent publication of articles in Book } \\
\text { of Proceedings. }\end{array}$ & Fevenths \\
\hline
\end{tabular}

Table 4. Summarized Research Methods

\begin{tabular}{|c|c|c|}
\hline $\begin{array}{l}\text { Research Steps / Research } \\
\text { questions }\end{array}$ & Data Collection Methods & $\begin{array}{ll}\text { Data Analysis } \\
\text { Method }\end{array}$ \\
\hline $\begin{array}{l}\text { What triggers a community } \\
\text { to mobilize themselves as } \\
\text { Green Brigade acting } \\
\text { towards a shared common } \\
\text { goal? }\end{array}$ & $\begin{array}{l}\text { Semi-structured and written } \\
\text { interviews with agents actively working } \\
\text { in the selected interventions and } \\
\text { projects. } \\
\text { Documents and media material } \\
\text { related to strategic planning. } \\
\text { Design thinking. }\end{array}$ & $\begin{array}{l}\text { Situational analysis and } \\
\text { content analysis to } \\
\text { extract indicators and } \\
\text { keywords. }\end{array}$ \\
\hline $\begin{array}{l}\text { What are the communication } \\
\text { patterns or structures when } \\
\text { shared responsibility on } \\
\text { waste is perceived by } \\
\text { different stakeholders and } \\
\text { actors at the University of } \\
\text { Minho? }\end{array}$ & $\begin{array}{l}\text { Observational learning and pilot } \\
\text { experiments. } \\
\text {. Desk research on policies. } \\
\text {. Delphi methods with stakeholders in } \\
\text { order revise their previous answers } \\
\text { confronted with the other members of } \\
\text { the panel. }\end{array}$ & $\begin{array}{l}\text { SMART methods to } \\
\text { build the structure of } \\
\text { data collected. }\end{array}$ \\
\hline $\begin{array}{l}\text { What are the best practices } \\
\text { with social impact of } \\
\text { grassroots movements that } \\
\text { close loops on resources and lead } \\
\text { to a Circular Economy? }\end{array}$ & $\begin{array}{l}\text { Triangulation to investigate the } \\
\text { opportunities for a closed loop and its } \\
\text { social } \\
\text { impacts. } \\
\text { Modelling and optimization of } \\
\text { decisions. }\end{array}$ & $\begin{array}{l}\text { Thematic analysis to } \\
\text { pinpoint the patterns. } \\
\text { The agents create } \\
\text { changes and the thesis } \\
\text { tells the story! }\end{array}$ \\
\hline
\end{tabular}

\section{Conclusions}

One of the factors why environmental awareness campaigns are very effective at schools is because of the community aspect, considering variables as peer pressure to 
influence and to determine the social values triggering behaviour change. When people feel watched because of an environmental campaign, they tend to change behaviour. A community is a dynamic involving organism influenced by a groupthink aspect as power of the dominant ones as well as the size of the group (members). The limited physical spaces of this research will be a university and neighbourhoods; nurturing spaces to gather data, to identify source separation practices and to analyse decision-making regulations.

Actions as engaging communities, involving people, leading by example, encouraging and enabling are determined by sociocultural factors that influence interventions and projects. People with negative perspectives on their communities make in general bad choices, while if there is trust and concern about the community, the tendency is to make better environmental choices. The smaller the group ( 6 to 5 people) the more pro-social actions individuals will have, because of a correlation when others get to know your actions, you will pay more attention on your actions. The more anonymous shared responsibility, the higher the chance of making negative choices and actions. The bigger the group, the higher tendency to put the responsibility on someone else.

\section{References}

AGYEMAN, A. Kollmuss, J. (2002). Mind the Gap: why do people act environmentally and what are the barriers to pro-environmental behavior? Environmental Education Research, 8 (2002), pp. 239260.

AJZEN, I. (1985). From intentions to actions: A theory of planned behavior. In J. Kuhl \& J. Beckman (Eds.), Action-control: From cognition to behavior (pp. 11-39). Heidelberg: Springer.

ALVES, Jorge Fernandes. (2002) A Indústria Têxtil do Vale do Ave. In MENDES, José Amado; FERNANDES, Isabel (Coord.) - Património e Indústria no Vale do Ave. Vilaf Nova de Famalicão: Adrave, 2002, p. 372-389.

BANDURA, A. (2001). Social cognitive theory: An agentive perspective. Annual Review of Psychology, 52, 1-26.

BECKER, E. and T. Jahn (eds) 1999 Sustainability and the Social Sciences. London: Zed Books (February 12, 2000).

BORGES, Orlando., A. B. Albuquerque, P. L. Marcelo. (2017) Relatório Anual dos Serviços de Águas e Resíduos em Portugal (RASARP), Volume 1 - Caraterização do setor de águas e resíduos. Edição Entidade Reguladora dos Serviços de Águas e Resíduos.

ELLEN MACARTHUR FOUNDATION (2012). Towards the Circular Economy: economic and business rationale for an accelerated transition. McKinsey / Ellen MacArthur Foundation. Retrieved from: http://www.ellenmacarthurfoundation.org/business/report

GOMES, Maria Margarida de Carvalho (2017). Artigo online ECOXXI. Published on Março 27, 2017. Retrieved from: https://ecoxxi.abae.pt/our news/a-maioria-das-eco-freguesias-2017-estao-emmunicipios-ecoxxi/

GUIMARÃES, Câmara de (2012). Agenda 21 do Eixo Atlântico - concelho de Guimarães. Modelo de Gestão de Resíduos. Retrieved from: http://www.cmguimaraes.pt/uploads/document/file/13353/Plano de gest o de residuos.pdf

GUIMARÃES MAIS VERDE, Eco-Revista. Junho 2015, no 1. Retrieved from: http://www.cmguimaraes.pt/frontoffice/pages/1123? news id $=2179$

GUIMARÃES 2012. Capital Europeia Da Cultura Impactos Económicos e Sociais. Universidade do Minho (UM), Junho de 2013. Rui Vieira de Castro. Vice-reitor da Universidade do Minho. Retrieved from: www.guimaraes2012-impactos.pt

HIREMATH, R.B., Balachandra, P., Kumar, B., Bansode, S.S. \& Murali, J. (2013) Indicator-based urban sustainability—A review [online]. Energy for Sustainable Development. 17 (6), pp. 555-563 
HONOR FAGAN, G. (2003). Sociological Reflections on Governing Waste. Irish Journal of Sociology ISSN 0791-6035 Vol. 12.1, 2003, pp.67-84. National University of Ireland, Maynooth. Retrieved from: http://eprints.maynoothuniversity.ie/466/1/sociological12.pdf

$\mathrm{H} \& \mathrm{M}$ website. RECYCLE YOUR CLOTHES. Retrieved from: http://about.hm.com/en/sustainability/get-involved/recycle-your-clothes.html

IRVING, Janis. (1982) Groupthink, 2d ed., Houghton Mifflin, Boston, 1982.

KIRCHHERR, Julian; Reike, Denise; Marko, Hekkert. (2017). Conceptualizing the circular economy: An analysis of 114 definitions Resources, Conservation and Recycling. Volume 127, December 2017, $\begin{array}{llll}\text { Pages } & 221 & \text {-232. Retrieved from: }\end{array}$ https://www.sciencedirect.com/science/article/pii/S0921344917302835\#!

KODA, Shino. (2012) Theoretical Approach to the Collaborative Environmental Activities: Household Waste Disposal towards Environmentally Friendly Daily Life. Graduate School of Energy Science Kyoto University Yoshida-honmachi, Sakyo-ku Kyoto, 606-850, JAPAN. International Journal of Humanities and Social Science. Vol. 2 No. 6 [Special Issue - March 2012]

LINDNER, Patrick; ROGERS, Heather; MOOIJ, Cynthia (2017). 'Circular Economy in Cities: A Strategic Approach Towards a Sustainable Society?'. Thesis submitted for completion of Master of Strategic Leadership towards Sustainability, Karlskrona, Sweden, v. Blekinge Institute of Technology.

MOUGE, P. \& Contractor, N. (2003). Theories of Communication Networks. Cambridge: Oxford University Press.

O'BRIEN, M. 1999a 'Rubbish values: reflections on the political economy of waste', Science as Culture, S(3): 269-95.

O'BRIEN, M 1999b 'Rubbish-power: towards a sociology of the rubbish society,' pp. 262-277 in J. Heam and S. Roseneil (eds) Consuming Cultures: Power and Resistance. London: Macmillan.

PINTO, Maria Elisabete de Sousa. Os «Homens de Couros»: marcas no presente do passado da indústria de curtumes em Guimarães. Universidade do Minho (2012). Retrieved from: https://www.ghp.ics.uminho.pt/eu/ficheiros\%20de\%20publicações/III\%20Relatório\%20Científi co $\% 20 \mathrm{FCT} /$ Elisabete $\% 20$ Pinto congresso $\% 20$ GMR.pdf

ROBY, Elizabeth. (2014) Sociological Approaches to Waste as a Social Problem: Environmental Burden, Race, Class, and Place. University at Buffalo, SUNY. Retrieved from: www.academia.edu/8520721/Sociological Approaches to Waste as a Social Problem Environ mental Burden Race Class and Place

ROSENLUND, Joacim. (2017) Improving regional waste management using the circular economy as an epistemic object. Environmental Sociology, Volume 3, 2017 - Issue 3. Article. Published online: 02 May 2017. Retrieved from

https://www.tandfonline.com/doi/full/10.1080/23251042.2017.1323154

SAWITRI, Dian R.; Hadiyanto, H.; Sudharto, P.Hadi (2015) Pro-environmental Behavior from a Social Cognitive Theory Perspective. Procedia Environmental Sciences. Volume 23, 2015, Pages 27-33. International Conference on Tropical and Coastal Region Eco-Development 2014 (ICTCRED 2014).

SEPÚlVEDA, D., Loureiro, I., Vilarinho, C., \& Carvalho, J. (2016). Municipal Waste Map : a Case Study of Guimarães , Portugal. City Hall of Guimarães and Universidade do Minho - ALGORITMI, CT2M,CVR.

SHEN, L.-Y., Jorge Ochoa, J., Shah, M.N. \& Zhang, X. (2011) The application of urban sustainability indicators - A comparison between various practices [online]. Habitat International. 35 (1), pp. 17-29.

STERN, P.C., T. Dietz, L. Kalof, G.A. Guagnano (1995). Values, beliefs, and pro-environmental action: Attitude formation toward emergent attitude objects. Journal of Applied Social Psychology, 26 (1995),pp. 1611-1620.

YEARLEY, S 1995 'Dirty connections: transnational pollution,' pp. 143-183 in J. Allen and C. Hamnett (eds) A Shrinking World? Oxford: Open University Press. 